\title{
ANALISIS STRUKTUR DAN STRATEGI NAFKAH RUMAHTANGGA PETANI SEKITAR KAWASAN HUTAN KONSERVASI DI DESA CIPEUTEUY, KABUPATEN SUKABUMI
}

\author{
Analysis of Household Livelihood Structure and Strategies of Farmers In ConservationForest \\ Areas, Case In The Village of Cipeuteuy, District Sukabumi
}

\author{
Novia Fridayanti*), Arya Hadi Dharmawan \\ Departemen Sains Komunikasi dan Pengembangan Masyarakat, Fakultas Ekologi Manusia, IPB \\ *) E-mail: therealnoviadarwis@gmail.com \\ Tanggal Diterima/Disetujui: 1 Februari 2013
}

\begin{abstract}
Citizens in the Cipeuteuy village still dependent their life on agricultural activities. The land that used to be in the National Park of Halimun-Salak Mountain areas and use the system through the principe of loan use. The livelihood strategy by people living in this village not only from agricultural sector, but also nonagricultural sector. There are many ways to implement the livelihood strategy, ranging from one sector to intensify, diversify income or dual income patterns, to spatial engineering or migration. But all sectors of the fixed income performed using livelihood asset. Five livelihood asset are natural capital, social capital, human capital, financial capital, and physic capital used in such a way as to support the sustainability of their livelihood strategies. Even longer, people tend to be more dependent on non-agricultural sector. But base their breadwinners are farmers. It is conclude that there has been a social transformation where the value of agriculture to the community has declined.
\end{abstract}

Key words: agrarian structure, farmer household, livelihood strategy

\begin{abstract}
ABSTRAK
Penduduk Desa Cipeuteuy masih menggantungkan kehidupan mereka dari kegiatan pertanian. Lahan yang digunakan adalah Taman Nasional Gunung Halimun Salak dan menggunakan prinsip pinjam pakai. Strategi nafkah warga yang tinggal di desa ini tidak hanya dari sektor pertanian, tapi juga sektor non pertanian. Terdapat berbagai cara penerapan struktur strategi penghidupan, mulai dari intensifikasi satu sektor, diversifikasi pendapatan atau pola nafkah ganda, rekayasa spasial atau migrasi. Namun, semua sektor pendapatan tetap menggunakan modal. Kelima modal yaitu modal sumberdaya alam, modal sosial, modal manusia, modal finansial, dan modal fisik digunakan sebagai cara untuk mendukung keberlanjutan strategi nafkah mereka. Bahkan semakin lama, warga cenderung lebih bergantung pada sektor non petanian. Namun basis nafkah mereka adalah sebagai petani. Hal ini dapat disimpulkan bahwa telah terjadi transformasi sosial dimana nilai pertanian terhadap masyarakat telah menurun.
\end{abstract}

Kata kunci : rumahtangga petani, strategi nafkah, struktur agraria

\section{PENDAHULUAN}

\section{Latar Belakang}

Hutan yang konversi pada tahun 1984 seluas 30,5 juta ha tersebut tinggal tersisa 8,4 juta ha. Hal ini karena sebagian besarnya telah dikonversi dan dipergunakan untuk kepentingan non-kehutanan, terutama untuk areal perkebunan dan lokasi transmigrasi. Untuk hutan produksi, data Desember 1983 menunjukkan bahwa areal yang dikuasai oleh 570 pemegang HPH sudah mencapai 62,29 juta ha (Wiradi, 2009a). Tentu ini adalah jumlah yang tidak sedikit mengingat jumlah luas hutan yang ada sekarang ini hanya mencapai +192 juta ha.

Salah satu perlindungan yang dilakukan adalah melalui penetapan sebagai taman nasional. Taman Nasional Gunung Halimun Salak (TNGHS) ditetapkan melalui Surat
Keputusan Menteri Kehutanan Nomor 282/Kpts-II/1992 pada tanggal 28 Februari 1992 dan selanjutnya melalui Surat Keputusan Menteri Kehutanan Nomor 175/KptsII/2003 tanggal 10 Juni 2003 dilakukan perluasan kawasan TNGH yang mana nama taman nasional berubah menjadi Taman Nasional Gunung Halimun-Salak dengan luas menjadi 113.357 ha. Balai pengelolaannya pun berubah nama menjadi Balai Taman Nasional Gunung HalimunSalak (BTNGHS).

Kawasan taman nasional ini mencatat bahwa terdapat 108 desa yang sebagian atau seluruh wilayahnya berada di dalam dan/atau berbatasan langsung dengan kawasan TNGHS. Banyaknya desa yang berada pada kawasan taman nasional menyebabkan penduduk di desa-desa tersebut turut memanfaatkan sumberdaya di hutan taman nasional ini. 
Pemanfaatan sumberdaya alam di dalam kawasan TNGHS ini telah berlangsung sejak sebelum kawasan ini ditetapkan sebagai taman nasional. Bentuk-bentuk pemanfaatan kawasan hutan tersebut turut memastikan bahwa keberadaan status baru sebagai taman nasional ini tentu tidak serta merta bisa diterima oleh semua pihak. Lahan yang awalnya bebas dimanfaatkan masyarakat untuk bertani dan mencari nafkah harus berubah status menjadi kawasan konservasi, terutama akibat perluasan kawasan TNGHS. Kepentingan ekologi yang dijunjung tinggi sebagai landasan dari penetapan dan perluasan kawasan konservasi ini ternyata harus bertarung dengan kepentingan ekonomi masyarakat.

Perluasan kawasan konservasi TNGHS turut memunculkan sistem zonasi baru yang mengekang lebih kebebasan masyarakat desa untuk menjangkau hutan. Penetapan zonasi yang terdiri dari zona inti, zona konservasi, dan zona pemanfaatan menjadi lebih luas dan makin membatasi akses masyarakat untuk memanfaatkan sumberdaya hutan dan lahan. Keadaan struktur agraria hutan yang meliputi pola penguasaan dan pemanfaatan lahan, akses, dan kontrol terhadap lahan dalam kawasan hutan menjadi buram karena status sebagai taman nasional.

Keadaan struktur agraria hutan ini mau tidak mau turut mempengaruhi penerapan strategi nafkah yang dijalankan oleh masyarakat desa. Pendapatan-pendapatan sebelumnya yang hanya bergantung pada sumberdaya hutan tak lagi bisa diandalkan karena keterbatasan akses. Masyarakat desa berusaha mencari strategi nafkah lain untuk bisa tetap bertahan memenuhi kebutuhan hidup rumahtangga mereka. Mulai dari menambah komoditas pertanian, menerapkan pola nafkah ganda, hingga strategi migrasi ke luar desa atau ke luar negeri (menjadi TKI).

Maka dari itu, penetapan status kawasan hutan ini sebagai taman nasional menjadi permasalahan yang patut mendapatkan perhatian. Akibat-akibat yang ditimbulkan dari permasalahan ini perlu dikaji lebih dalam mengingat kawasan hutan dan sumberdaya di dalamnya telah menjadi medan tempur berbagai kepentingan yang saling berbenturan satu sama lain.

\section{Rumusan Masalah}

Permasalahan-permasalahan yang terjadi pada masyarakat sekitar kawasan TNGHS ini menarik perhatian peneliti sehingga dirumuskanlah pertanyaan penelitian yakni: (1) bagaimana status penguasaan lahan rumahtangga petani setelah perluasan kawasan TNGHS? (2) bagaimana bentuk struktur nafkah rumahtangga petani pada status penguasaan lahan yang unsecured di kawasan TNGHS?; dan (3) bagaimana penerapan strategi nafkah rumahtangga petani setelah perluasan kawasan TNGHS?

\section{Tujuan Penelitian}

Tujuan penelitian ini antara lain: (1) untuk menguraikan status penguasaan lahan rumahtangga petani setelah perluasan kawasan TNGHS; (2) untuk menganalisis bentuk struktur nafkah rumahtangga petani pada status penguasaan lahan yang unsecured di kawasan TNGHS; dan (3) untuk menganalisis penerapan strategi nafkah rumahtangga petani setelah perluasan kawasan TNGHS.

\section{Kegunaan Penelitian}

Penelitian ini diharapkan dapat memberikan manfaat bagi akademisi sebagai bahan literature terkait topik livelihood studies, pertanian, dan pedesaan; bagi masyarakat bisa menjadi wacana dan menambah pengetahuan bagi masyarakat umum terkait dengan kondisi pertanian dan permasalahan strategi nafkah masyarakat; dan bagi BTNGHS dapat menjadi informasi dan data untuk membuat kebijakan yang sesuai terkait penguasaan, pengelolaan, serta akses dan kontrol terhadap lahan.

\section{TINJAUAN PUSTAKA}

\section{Hutan dan Areal Konservasi}

Sebelum membahas lebih dalam mengenai kawasan hutan konservasi, terlebih dahulu kita harus mengetahui sebenarnya apa yang dimaksud dengan hutan. Dalam Undang-Undang RI Nomor 5 Tahun 1967 Pasal 1 dijelaskan berbagai definisi yang berkaitan dengan hutan, yaitu:

1. "Hutan" ialah suatu lapangan bertumbuhan pohonpohon yang secara keseluruhan merupakan persekutuan hidup alam hayati beserta alam lingkungannya dan yang ditetapkan oleh Pemerintah sebagai hutan.

2. "Hasil Hutan" ialah benda-benda hayati yang dihasilkan dari hutan.

3. "Kehutanan" ialah kegiatan-kegiatan yang bersangkutpaut dengan hutan dan kepengurusannya.

4. "Kawasan Hutan" ialah wilayah-wilayah tertentu yang oleh Menteri ditetapkan untuk dipertahankan sebagai hutan tetap.

Lahan merupakan basis bagi berlangsungnya kehidupan rumahtangga petani karena dari hasil pertanian petani memperoleh penghasilan (Turasih, 2011). Keterbatasan lahan pertanian menjadi salah satu penyebab ketergantungan masyarakat terhadap keberadaan hutan disekelilingnya (Sutaryono, 2008). Nurhaeni (2009) mengungkapkan bahwa penunjukan areal konservasi berarti pengalihfungsian hutan dari hutan produksi menjadi hutan konservasi sudah tentu mempengaruhi kehidupan masyarakat di sekitar kawasan hutan. Penunjukan areal konservasi sendiri merupakan salah satu upaya dari pemerintah untuk melindungi hutan sebagai bentuk pelestarian alam.

Dalam pasal 1 ayat 13 UU Nomor 5 tahun 1990, dijelaskan bahwa kawasan pelestarian alam adalah kawasan dengan ciri khas tertentu, baik di darat maupun di perairan yang mempunyai fungsi perlindungan sistem penyangga kehidupan, pengawetan keanekaragaman jenis tumbuhan dan satwa, serta pemanfaatan secara lestari sumber daya alam hayati dan ekosistemnya. Kawasan pelestarian yang diatur pada pasal 29 meliputi Taman Nasional, Taman Hutan Raya, dan Taman Wisata Alam, meliputi areal daratan dan perairan.

Menurut Ngadiono (2004) dalam Nurhaeni (2009), taman nasional merupakan kawasan pelestarian alam yang mempunyai ekosistem asli, dikelola dengan sistem zonasi yang dimanfaatkan untuk tujuan penelitian, ilmu pengetahuan, pendidikan, menunjang budaya, pariwisata, dan rekreasi. Fungsi taman nasional adalah sebagai kawasan perlindungan sistem penyangga kehidupan, pengawetan keragaman jenis tumbuhan dan satwa, serta 
kawasan pemanfaatan secara lestari potensi sumberdaya alam hayati dan ekosistemnya.

Sependapat dengan hal tersebut, Arifin (1990) dalam Nurhaeni (2009) juga mengemukakan bahwa pembentukan taman nasional merupakan salah satu upaya melindungi tipe-tipe ekosistem yang khas, sehingga dalam langkah gerak pembangunan yang gencar ini tetap dapat dipelihara keselarasan antara manusia dengan ekosistem dalam rangkaian kurun waktu dan gerak yang dinamis. Kondisi demikian diharapkan agar ekosistem tetap berada dalam keseimbangan.

Dalam Pamulardi (1995), beberapa pengertian sistem zonasi dalam Taman Nasional, antara lain:

1. Zona Inti adalah bagian kawasan Taman Nasional yang mutlak dilindungi dan tidak diperbolehkan adanya perubahan apapun oleh aktivitas manusia.

2. Zona pemanfaatan adalah bagian dari kawasan Taman Nasional yang dijadikan pusat rekreasi dan kunjungan wisata.

3. Zona lain adalah zona di luar zona inti dan zona pemanfaatan karena fungsi dan kondisinya tetap sebagai zona tertentu, seperti zona rimba, zona pemanfaatan tradisional, zona rehabilitasi, dan sebagainya.

\section{Penetapan Konservasi dan Perubahan Struktur Agraria}

Pengertian agraria dalam arti sempit hanyalah meliputi permukaan bumi yang disebut tanah, sedangkan pengertian agraria dalam arti luas meliputi bumi, air, ruang angkasa, dan kekayaan alam yang terkandung di dalamnya (Santoso , 2005). Dalam masyarakat agraris, masalah pemilikan dan penguasaan tanah merupakan faktor penentu bangunan masyarakat secara keseluruhan. Hakikat struktur agraria adalah menyangkut masalah susunan pembagian tanah, penyebaran atau distribusinya, yang pada gilirannya menyangkut hubungan kerja dalam proses produksi (Wiradi, 2009b).

Namun tata hubungan yang sudah mapan dalam struktur agraria dapat berubah akibat bekerjanya berbagai faktor yang berkerja dan mempengaruhi. Proses perubahan tata hubungan ini sendiri dapat terjadi secara smooth, tetapi juga dapat terjadi melalui, atau juga menimbulkan, suatu gejolak sosial (Wiradi, 2009b). Perubahan struktur agraria berimplikasi pada menguatnya proses marginalisasi yang ditunjukkan oleh praktek-praktek penguasaan lahan, penggunaan tanah, dan pola nafkah (Sihaloho, 2004).

Dalam kasus di TNGHS, karena adanya perbedaan status hak kepemilikan antara masyarakat adat dan negara, maka Nurhaeni (2009) menjelaskan bahwa masyarakat harus rela kehilangan setengah tanah garapan mereka ketika hutan tersebut dijadikan sebagai areal konservasi. Penunjukan areal konservasi tersebut, turut berimbas pada luas lahan garapan masyarakat yang semakin berkurang karena lahan tersebut telah diklaim sebagai taman nasional oleh pihak TNGHS. Marina (2011) menjelaskan bahwa sistem zonasi sebenarnya sama artinya dengan sistem pengelolaan hutan secara adat. Yang menjadi permasalahan adalah ketika kawasan pemukiman, sawah, dan ladang milik masyarakat dijadikan zona rimba dan zona rehabilitasi yang tidak boleh dimasuki masyarakat

\section{Pola Pengusaan Lahan}

Menurut Wiradi (2009b), dalam pengertian struktur agraria ini perlu juga dibedakan antara istilah pemilikan, penguasaan, dan pengusahaan tanah. Kata "pemilikan" menunjuk kepada penguasaan formal, sedangkan "penguasaan" menunjuk kepada penguasaan efektif. Misalnya sebidang tanah disewakan kepada orang lain maka orang lain itulah yang secara efektif menguasai. Kata "pengusahaan" menunjuk kepada bagaimana caranya sebidang tanah diusahakan secara produktif.

Dalam pola penguasaan lahan, ada yang disebut dengan tanah sewa yaitu tanah dimana si penyewa membayar uang sewa kepada pemilik tanah (Santoso, 2005). Wiradi dan Makali (2009) juga mengemukakan bahwa sistem sewa ialah penyerahan sementara hak penguasaan tanah kepada orang lain, sesuai dengan perjanjian yang dibuat bersama oleh pemilik dan penyewa.

Di kawasan TNGHS, Marina (2011) mengemukakan dua status kepemilikan yaitu sebagai lahan titipan para leluhur, seluruh sumberdaya alam ini diklaim sebagai milik adat dan bersifat komunal, hanya boleh dipergunakan dan dimanfaatkan untuk hidup namun tidak boleh untuk dijual dan dimiliki secara individual. Sedangkan hak kepemilikan lain adalah milik negara sebagaimana diatur dalam pasal 34 UU No. 5 Tahun 1990 mengenai Konservasi Sumberdaya Alam dan Ekosistemnya, pengelolaan taman nasional dilaksanakan oleh pemerintah yang dalam hal ini oleh Kementerian Kehutanan.

\section{Konsep Strategi Nafkah}

Dharmawan (2007) mengemukakan bahwa dalam sosiologi nafkah, pengertian strategi nafkah lebih mengarah pada pengertian livelihood strategy (strategi penghidupan) daripada means of living strategy (strategi bertahan hidup). Strategi nafkah adalah taktik dan aksi yang dibangun oleh individu ataupun kelompok dalam rangka mempertahankan kehidupan mereka dengan tetap memperhatikan eksistensi infrastruktur sosial, struktur sosial dan sistem nilai budaya yang berlaku.

Menurut Dharmawan (2007), ada dua tradisi pemikiran yang mendasari dinamika sistem penghidupan dan nafkah pedesaan, yaitu:

a. Mahzab Bogor, dimana strategi penghidupan dan nafkah pedesaan dibangun selalu menunjuk ke sektor pertanian (dalam arti luas). Basis nafkah rumahtangga petani adalah segala aktivitas ekonomi pertanian dan ekonomi nonpertanian yang sangat ditentukan oleh sistem sosial-budaya setempat. Dari dua kombinasi basis nafkah, setiap individu memainkan kombinasi modal-keras berupa fisik, finansial, dan tanah dengan modal-lembut berupa keterampilan dan intelektual SDM guna menghasilkan sejumlah strategi penghidupan.

b. Mahzab Barat yang memandang sistem penghidupan dan nafkah pedesaan dalam setting dinamika sosioekologis suatu ekosistem. Dalam setting ini, sub-sistem sosial dan sub-sistem ekologi memungkinkan tersedianya pilihan-pilihan strategi nafkah bagi petani. Oleh karena itu, bentuk-bentuk strategi nafkah yang terbangun ditentukan 
bagaimana petani dan rumahtangganya memainkan kombinasi-kombinasi sumberdaya nafkah yang tersedia bagi mereka.

Strategi nafkah ialah penghidupan yang terdiri dari aset (alam, fisik, manusia, modal keuangan, dan modal sosial), kegiatan, dan akses (yang dimediasi oleh kelembagaan dan hubungan sosial) yang bersama-sama menentukan kehidupan individu atau rumahtangga (Ellis 2000). Menurut Masithoh (2005) dalam Niswah (2011), sumber nafkah adalah berbagai sumberdaya yang dapat digunakan oleh individu maupun keseluruhan anggota rumahtangga petani untuk melaksanakan strategi nafkah guna mempertahankan keberlangsungan hidupnya paling tidak untuk memenuhi kebutuhan subsisten ataupun dalam rangka meningkatkan kualitas hidup suatu rumahtangga petani. Penerapan strategi nafkah, rumah tangga petani memanfaatkan berbagai sumberdaya yang dimiliki dalam upaya untuk dapat bertahan hidup (Scoones 1998 dalam Turasih 2011). Terdapat lima bentuk modal atau biasa disebut livelihood asset. Menurut Ellis (2000), kelima bentuk modal tersebut antara lain:

\section{a. Modal Sumberdaya Alam (Natural Capital)}

Modal ini bisa juga disebut sebagai lingkungan yang merupakan gabungan dari berbagai faktor biotik dan abiotik di sekeliling manusia. Modal ini dapat berupa sumberdaya yang bisa diperbaharui maupun tidak bisa diperbaharui. Contoh dari modal sumberdaya alam adalah air, pepohonan, tanah, stok kayu dari kebun atau hutan, stok ikan di perairan, maupun sumberdaya mineral seeprti minyak, emas, batu bara, dan lain sebagainya.

\section{b. Modal Fisik (Physical Capital)}

Modal fisik merupakan modal yang berbentuk infrastruktur dasar seperti saluran irigasi, jalan, gedung, dan lain sebagainya.

\section{c. Modal Manusia (Human Capital)}

Modal ini merupakan modal utama apalagi pada masyarakat yang dikategorikan "miskin". Modal ini berupa tenaga kerja yang tersedia dalam rumahtangga yang dipengaruhi oleh pendidikan, keterampilan, dan kesehatan untuk dapat memenuhi kebutuhan hidupnya.

\section{d. Modal Finansial (Financial Capital and Subtitutes)}

Modal ini berupa uang, yang digunakan oleh suatu rumahtangga. Modal ini dapat berupa uang tunai, tabungan, ataupun akses dan pinjaman.

\section{e. $\quad$ Modal Sosial (Social Capital)}

Modal ini merupakan gabungan komunitas yang dapat memberikan keuntungan bagi individu atau rumahtangga yang tergabung di dalamnya. Contoh modal sosial adalah jaringan kerja (networking) yang merupakan hubungan vertikal maupun hubungan horizontal untuk bekerja sama dan memberikan bantuan untuk memperluas akses terhadap kegiatan ekonomi.

\section{Jenis-jenis Strategi Nafkah}

Ellis (2000) mengemukakan tiga klasifikasi sumber nafkah (income source) yaitu:

a. Sektor farm income: sektor ini mengacu pada pendapatan yang berasal dari tanah pertanian milik sendiri, baik yang diusahakan oleh pemilik tanah maupun diakses melalui sewa menyewa atau bagi hasil. Strategi on farm merujuk pada nafkah yang berasal dari pertanian dalam arti luas.

b. Sektor off-farm income: sektor ini mengacu pada pendapatan di luar pertanian, yang dapat berarti penghasilan yang diperoleh berasal dari upah tenaga kerja, sistem bagi hasil, kontrak upah tenaga kerja non upah, dan lain-lain, namun masih dalam lingkup sektor pertanian.

c. Sektor non-farm income: sektor ini mengacu pada pendapatan yang bukan berasal dari pertanian, seperti pendapatan atau gaji pensiun, pendapatan dari usaha pribadi, dan sebagainya.

Merujuk pada Scoones (1998) dalam Turasih (2011), terdapat tiga klasifikasi strategi nafkah (livelihood strategy) yang mungkin dilakukan oleh rumahtangga petani, yaitu:

a. Rekayasa sumber nafkah pertanian, yang dilakukan dengan memanfaatkan sektor pertanian secara efektif dan efisien baik melalui penambahan input eksternal seperti teknologi dan tenaga kerja (intensifikasi), maupun dengan memperluas lahan garapan (ekstensifikasi).

b. Pola nafkah ganda (diversifikasi), yang dilakukan dengan menerapkan keanekaragaman pola nafkah dengan cara mencari pekerjaan lain selain pertanian untuk menambah pendapatan, atau dengan mengerahkan tenaga kerja keluarga (ayah, ibu, dan anak) untuk ikut bekerjaselain pertanian dan memperoleh pendapatan.

c. Rekayasa spasial (migrasi), merupakan usaha yang dilakukan dengan melakukan mobilitas ke daerah lain di luar desanya, baik secara permanen maupun sirkuler untuk memperoleh pendapatan.

\section{Penetapan Konservasi dan Penerapan Strategi Nafkah}

Dalam penelitiannya terhadap petani tembakau, Widianto et al. (2010) mengemukakan bahwa sistem nafkah yang dibangun sangat dipengaruhi oleh etika moral petani baik pada level individu, rumahtangga, hingga komunitas, yang terdiri dari etika sosial-kolektif dan etika individualmaterialism. Etika sosial-kolektif masih tampak pada beberapa aktivitas ekonomi petani. Namun diakui bahwa beberapa perilaku ekonomi berbasis etika resiprositas perlahan melemah, seperti perubahan sistem "royongan" kesistem upah. Dinamika strategi nafkah petani tembakau dilihat pada berbagai lapisan. Ada petani berlahan luas dan petani berlahan sempit dengan basis produksi yang terbagi dua pula, yakni rumahtangga petani tembakau akan berproduksi berbasiskan sawah atau tegal (pegunungan).

Aktivitas ekonomi yang berbeda terjadi pada petani lahan kering dimana terjadi perubahan dari aktivitas ekonomi berbasis lahan kering dan bersifat tradisional/subsisten menjadi aktivitas ekonomi yang menunjukkan ciri-ciri komersil (Sunarsih, 2004). Ciri yang menonjol dari aktivitas ekonomi tradisional adalah dalam hal pemanfaatan hasil produksi yang sebagian besar atau seluruhnya ditujukan untuk memenuhi kebutuhan subsisten (secukup hidup) 
keluarga. Sedangkan aktivitas ekonomi komersial memiliki ciri-ciri menonjol yaitu: (1) tujuan produksi untuk pasar; (2) teknologi yang digunakan dianggap lebih maju; (3) jaringan sistem produksi dan distribusi luas; (4) modal dan masukan yang dibutuhkan relatif lebih besar; dan (5) tenaga kerja dari luar keluarga. Strategi nafkah lain dapat dilihat pada Taman Nasional Karimunjawa (TNKJ) yang memberi peluang baru untuk nelayan kompresor di sekitar TNKJ memperoleh penghasilan tambahan. Sebelum penetapan zonasi, strategi nafkah ganda mengandalkan sektor perikanan dan jasa sedangkan setelah penetapan zonasi sumber nafkah lebih bervariasi (Priyanto, 2011).

Dalam penelitian Turasih (2011), strategi nafkah pertanian rumahtangga petani kentang di Dataran Tinggi Dieng terdiri dari dua sektor yaitu on farm dan off farm. Strategi on farm berupa pertanian dengan komoditas utama tentu saja tanaman kentang dan komoditas lain seperti kobis, koncang (bawang daun), cabe bandung, dan sebagian ada yang menanam kacang dieng, yang hanya menjadi komoditas sampingan yang tidak diprioritaskan. Sedangkan strategi nafkah non farm yang banyak dikerjakan adalah menjadi pedagang karena lokasi Desa Karangtengah cukup jauh dari pasar dan kota kabupaten.

\section{KERANGKA PEMIKIRAN}

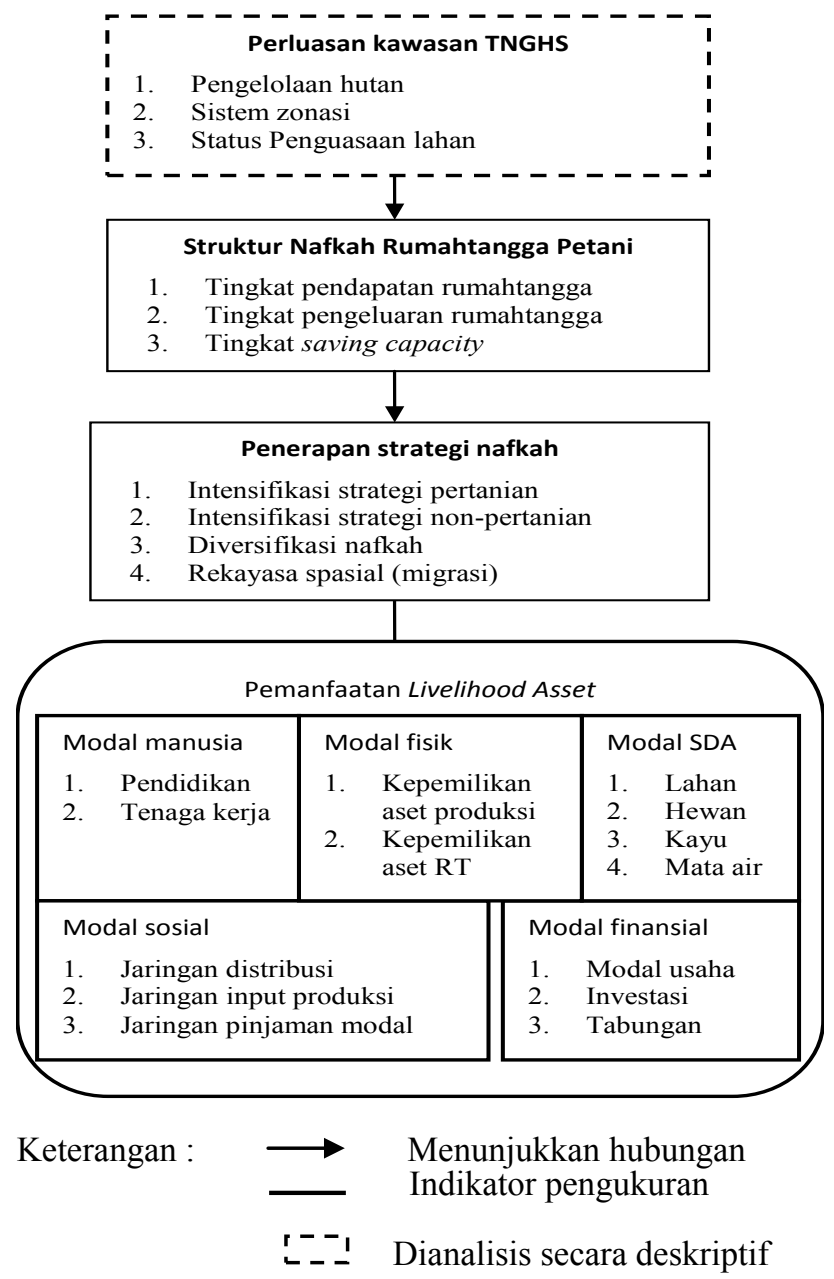

Gambar 1 Logical Framework: Aspek-aspek yang menjadi sasaran penelitian

\section{HIPOTESIS PENELITIAN}

Berdasarkan dari kerangka pemikiran yang telah dibuat, maka hipotesis yang dapat ditarik adalah:

1. Diduga ada perbedaan dalam status penguasaan lahan rumahtangga petani setelah perluasan kawasan TNGHS.

2. Diduga struktur nafkah rumahtangga petani dipengaruhi oleh status penguasaan lahan yang unsecured dari kawasan TNGHS.

3. Diduga terdapat beragam strategi nafkah yang diterapkan oleh rumahtangga petani setelah perluasan kawasan TNGHS.

\section{METODOLOGI}

\section{Ruang Lingkup Penelitian}

Metode penelitian ini menggunakan pendekatan kuantitatif yang didukung oleh pendekatan kualitatif. Dalam ranah pendekatan kuantitatif, peneitian ini merupakan jenis penelitian survey. Penelitian survey adalah penelitian yang mengambil sampel dari satu popuasi dan menggunakan kuesioner sebagai alat pengumpulan data pokok (Singarimbun dan Effendi 1989). Sedangkan dalam ranah pendekatan kualitatif, penelitian ini menggunakan metode studi kasus, pengamatan, dan wawancara.

\section{Lokasi dan Waktu Penelitian}

Penelitian yang dilaksanakan pada bulan September November tahun 2012 ini berlokasi di desa yang berada di sekitar kawasan Taman Nasional Gunung HalimunSalak yaitu Desa Cipeuteuy, Kecamatan Kabandungan, Kabupaten Sukabumi, dengan alasan: (1) Wilayah Desa Cipeuteuy telah mengalami perubahan struktur agraria ketika terjadi perluasan areal TNGHS dan (2) sebagian besar penduduk di Desa Cipeuteuy masih memanfaatkan sumberdaya di hutan Taman Nasional Gunung HalimunSalak untuk mencari nafkah.

\section{Teknik Pemilihan Responden}

Peneliti mengambil unit analisis yaitu rumahtangga yang salah satu anggota rumahtangganya bekerja sebagai petani dengan sampel berupa rumahtangga. Peneliti terlebih dahulu memilih secara purposive Dusun Cisarua sebagai fokus penelitian karena mayoritas petani yang memanfaatkan lahan taman nasional berada di dusun ini. Setelahnya, membuat sampling frame dari seluruh rumahtangga petani di dusun tersebut. Baru kemudian diambil sampel sebanyak 35 rumah tangga melalui teknik penarikan sampel acak sederhana (simple random sampling). Nama-nama informan diperoleh melalui teknik penarikan sampel bola salju (snowball sampling) yakni mengetahui satu nama informan dan dari informan tersebut kemudian diketahui nama informan-informan yang lain.

\section{Teknik Pengolahan Data}

Data yang diperoleh, baik primer maupun sekunder, direkapitulasi dan diolah menggunakan program aplikasi Microsoft Excel. Data mengenai tingkat pendapatan diolah dengan cara pengkategorian (pertanian dan non pertanian) dan dicari rata-rata pendapatannya per tahun. Kemudian 
setelah itu dibuat kurva sebaran normal untuk melihat tingkatan pendapatan dari masing-masing responden berdasarkan standar deviasinya. Perhitungan tingkat pendapatan, tingkat pengeluaran, dan tingkat saving capacity serta tingkat kemiskinan menggunakan tabel frekuensi dan setelahnya disajikan dalam bentuk bar chart. Cara menghitungnya adalah sebagai berikut:

1. Pendapatan pertanian (a) dihitung dari pemasukan hasil panen seluruh tanaman tanaman pertanian dikurangi pengeluaran produksi (upah tenaga kerja, pupuk, dan pestisida).

2. Pendapatan non-pertanian (b) dihitung dari pemasukan hasil pekerjaan di luar pertanian dikurangi biaya-biaya produksi (bensin, modal awal untuk warung, dan sebagainya)

3. Pendapatan total rumahtangga (c) dihitung dari pendapatan pertanian ditambah pendapatan nonpertanian: $(\mathrm{a})+(\mathrm{b})=(\mathrm{c})$

4. Pengeluaran rumahtangga (d) dihitung dari penjumlahan seluruh pengeluaran sehari-hari dalam setahun (makanan, listrik, pendidikan, kesehatan, dan transportasi)

5. Saving Capacity (e) dihitung dari pendapatan total rumahtangga dikurangi pengeluaran rumahtangga: (c) $-(\mathrm{d})=(\mathrm{e})$

\section{KARAKTERISTIK RESPONDEN DAN SISTEM PERTANIAN}

\section{Pemerintahan dan Kependudukan Desa Cipeuteuy}

Dalam administrasi pemerintahan, Desa Cipeuteuy terletak di Kecamatan Kabandungan, Kabupaten Sukabumi, Provinsi Jawa Barat. Desa Cipeuteuy membentuk desa sendiri setelah berpisah dari Desa Kabandungan yang mengalami pemekaran wilayah pada tahun 1980 menjadi Desa Kabandungan dan Desa Cipeuteuy. Desa Cipeuteuy terbagi ke dalam lima dusun yakni Dusun Cipeuteuy, Dusun Pandan Arum, Dusun Lewiwaluh, Dusun Arendah, dan Dusun Cisarua.

Menurut data profil desa tahun 2011, Desa Cipeuteuy yang terletak di sekitar kawasan hutan TNGHS ini memiliki luas wilayah 3.756,60 hektar. Jumlah penduduk Desa Cipeuteuy yang tercatat pada tahun 2011 sebanyak 6.842 jiwa yang terdiri dari 3.503 laki-laki dan 3.339 perempuan. Jumlah kepala keluarga yang tercatat sebanyak $1.777 \mathrm{KK}$.

\section{Tingkat Penguasaan Lahan}

Tingkat penguasaan lahan diamati dari luas lahan yang dikuasai dan digarap oleh responden penelitian untuk kegiatan pertaniannya. Responden penelitian bisa jadi tidak hanya bergantung pada satu lahan garapan saja. Artinya untuk memaksimalkan kegiatan pertaniannya, ada beberapa responden menggunakan lebih dari satu lahan. Misalnya responden yang telah memiliki lahan sendiri namun tetap memanfaatkan lahan di kawasan TNGHS. Bentuk-bentuk penguasaan lahan responden terdiri dari lima jenis yaitu milik sendiri, pinjam pakai TNGHS, eks lahan HGU PT. Intan Hepta, bagi hasil, dan tidak mempunyai lahan. Maka dari itu tabel 1 di bawah ini menampilkan persentase responden yang menguasai dan memanfaatkan lahan, baik hanya pada satu bentuk penguasaan atau lebih.
Tabel 1 Persentase tingkat penguasaan lahan responden berdasarkan bentuk penguasaan lahannya tahun 2012

\begin{tabular}{lc}
\hline \multicolumn{1}{c}{ Bentuk penguasaan lahan } & Persentase responden (\%) \\
\hline Milik sendiri & $9 \%$ \\
Pinjam pakai lahan TNGHS & $54 \%$ \\
Eks HGU Perkebunan Intan Hepta & $6 \%$ \\
Bagi hasil & $6 \%$ \\
Penguasaan lebih dari satu lahan & $20 \%$ \\
Tidak punya lahan & $6 \%$ \\
\hline
\end{tabular}

Mata pencarian masyarakat di Desa Cipeuteuy memang masih bergantung pada pertanian. Lebih dari 50 persen warganya berprofesi sebagai petani atau buruh tani. Berdasarkan wawancara dengan responden penelitian yang berjumlah 35 orang, terlihat bahwa tingkat pendidikan responden rata-rata hanya sampai pada tingkat sekolah dasar (SD) yaitu sebesar 61 persen. Ada juga yang hingga tingkat SMP sebesar 16 persen dan tingkat SMA sebesar 12 persen. Sisanya ada yang tidak taman SD dan ada pula yang berasal daari lulusan madrasah. Sedangkan untuk tingkat penguasaan lahan, persentase responden paling besar adalah yang menguasai lahan melalui pinjam pakai lahan TNGHS yaitu 54 persen. Kemudian responden yang memiliki lahan sendiri sebesar sembilan persen, lahan bagi hasil dan pinjam pakai Perhutani sebesar enam persen. Responden yang tidak memiliki lahan juga berada pada angka enam persen. Sisanya adalah responden yang menggunakan lebih dari satu lahan garapan untuk kegiatan pertaniannya yaitu sebesar 20 persen.

Berdasarkan karakteristik sistem pertaniannya, pertanian yang dilakukan oleh petani di desa ini terbagi dua jenis yaitu petani sayur dan petani padi. Petani sayur berorientasi pada produksi yang artinya memaksimalkan hasil produksi karena tujuan ekonomi. Hasil panen sayuran dijual untuk memperoleh pendapatan guna memenuhi kebutuhan sehari-hari. Berbeda dengan hal tersebut, petani padi justru berorientasi pada konsumsi karena hasil panen padi digunakan untuk kebutuhan sehari-hari. Hasil panen padi tidak dijual melainkan dikonsumsi sendiri oleh rumahtangga petani yang menanamnya. Jenis tanaman yang biasanya ditanam oleh para petani diantaranya tanaman kacang, cabai, caisin, singkong, dan sebagainya. Tanaman-tanaman ini dipilih karena sistem penanamannya yang mudah, waktu panen yang singkat, serta harga jualnya yang cukup tinggi. Tentu saja jika musim sedang normal, bukan pada musim paceklik. Sistem pertanian warga sendiri masih bergantung pada keberadaan sumberdaya dari kawasan hutan TNGHS. Lahan yang dipergunakan oleh mayoritas petani berada dalam kawasan TNGHS melalui sistem "pinjam-pakai". Meskipun ada juga yang memiliki lahan sendiri. Begitu pun untuk irigasi diambil dari mata air dalam kawasan hutan. Akses permodalan dan kelembagaan pertanian telah ada untuk membantu kelompok-kelompok tani, namun fungsinya masih belum dimanfaatkan dengan maksimal.

\section{STRUKTURAGRARIADANSTATUS PENGUASAAN LAHAN}

Pengelolaan hutan TNGHS pada masa sebelum ditunjuk menjadi areal konservasi berada di tangan Perum Perhutani. Pada masa itu, masyarakat masih memiliki 
kebebasan untuk mengakses sumberdaya dalam hutan. Namun kebebasan akses yang diperoleh masyarakat dalam memanfaatkan kawasan hutan tidak diikuti dengan adanya hak yang sah atas penguasaan atas lahan tersebut. Artinya, masyarakat tidak memiliki kekuatan untuk merebut kembali lahan garapan mereka jika digusur oleh Perhutani selaku pengelola lahan hutan. Bisa dikatakan, masyarakat hanya memiliki hak pemanfaatan terhadap lahan tersebut namun tidak secara sah memiliki. Kemudian berdasarkan SK Menteri Kehutanan No. 175/Kpts-II/2003, dilakukan perluasan kawasan taman nasional menjadi TNGHS. Perluasan kawasan TNGHS ini menjadikan lahan masyarakat masuk ke dalam kawasan TNGHS. Meskipun terdapat zona-zona yang sebenarnya bisa dimanfaatkan oleh masyarakat, namun lahan-lahan garapan masyarakat sebelum berstatus taman nasional telah memasuki zona inti atau zona rimba.

Tentu saja status penguasaan lahan kawasan TNGHS yang tidak jelas ini menyebabkan ketidakamanan petani dalam menggunakan lahan tersebut. Apalagi mayoritas lahan yang digunakan oleh petani di desa ini adalah lahan pinjam pakai dari pihak TNGHS dan eks HGU PT. Intan Hepta. Kedua jenis lahan tersebut merupakan lahan milik negara. Ketergantungan terhadap lahan milik negara ini tentu mempengaruhi cara berstrategi petani dalam mencari nafkah bagi rumahtangganya. Hasil penelitian memperlihatkan bahwa sektor non-pertanian telah menjadi tempat bergantung masyarakat selain pertanian. Strategi nafkah masyarakat di desa ini cukup banyak memanfaatkan sektor non-pertanian seperti menjadi pedagang di pasar, pedagang ternak, pedagang warung, buruh bangunan, buruh hutan, hingga tukang ojek. Macam-macam mata pencaharian yang dilakukan rumahtangga petani ini memperlihatkan bahwa mereka telah cukup jauh memanfaatkan sektor ini di samping basis nafkah utama mereka yaitu pertanian. Maka dari itu, pengelolaan kawasan TNGHS yang dijalankan oleh BTNGHS mempengaruhi status penguasaan lahan masyarakat, terutama lahan yang selama ini digunakan oleh mereka untuk kegiatan pertanian. Status penguasaan lahan yang berada di atas perjanjian yang tidak jelas membuat masyarakat takut untuk mengembangkan pertaniannya. Jika begitu, masyarakat harus memiliki pekerjaan lain selain petani untuk memenuhi kebutuhan ekonomi mereka yang juga terus meningkat.

\section{STRUKTUR NAFKAH RUMAHTANGGA PETANI}

Tingkat pendapatan dari sektor pertanian terdiri dari onfarm dan off-farm, yaitu sebagai petani dan buruh tani. Petani di Desa Cipeuteuy terdiri dari dua jenis yaitu petani sayur dan petani padi. Namun mayoritas mereka menjadi petani sayur untuk memperoleh pendapatan berbentuk uang dari hasil produksinya. Hasil penelitian menyatakan bahwa jumlah pendapatan sebagai petani sayur menyumbang ratarata sekitar 78 persen pada golongan tinggi, 46 persen pada golongan sedang, dan 74 persen pada golongan rendah. Berbeda dengan hal tersebut, hasil produksi dari pertanian padi biasanya hanya dikonsumsi oleh rumahtangga petani itu sendiri (pertanian subsisten).

Pendapatan dari sektor non pertanian (non-farm) diperoleh dari pekerjaan seperti buruh bangunan, tukang ojek, pedagang, usaha warung, buruh hutan, atau menjadi guru. Berdasarkan hasil penelitian, pemasukan terbesar pada golongan pendapatan tinggi dari sektor non-pertanian berasal dari usaha berdagang di warung yaitu 34 persen.
Lalu pada golongan pendapatan sedang, pemasukan terbesar berasal dari kiriman anggota keluarga yang bekerja di luar desa yaitu sebesar 32 persen. Terakhir pada golongan pendapatan rendah, pemasukan terbesar dari pekerjaan sebagai buruh bangunan yaitu mencapai 37 persen.

Kontribusi pendapatan pertanian dan sektor non-pertanian terhadap rata-rata pendapatan rumahtangga per tahun hampir seimbang. Pendapatan yang diperoleh oleh responden dari sektor non-pertanian adalah sebesar 43 persen. Persentase ini hampir menyamai pendapatan dari sektor pertanian yaitu 57 persen.

Tabel 2 Persentase pendapatan responden per tahun dari sektor pertanian pada setiap golongan pendapatan menurut sumbernya tahun 2012

\begin{tabular}{|c|c|c|c|}
\hline \multirow{2}{*}{$\begin{array}{c}\text { Sumber } \\
\text { pendapatan }\end{array}$} & \multicolumn{3}{|c|}{$\begin{array}{l}\text { Persentase pendapatan rumahtangga/ } \\
\text { tahun }(\%)\end{array}$} \\
\hline & $\begin{array}{l}\text { Petani } \\
\text { Golongan } \\
\text { Tinggi }\end{array}$ & $\begin{array}{c}\text { Petani } \\
\text { Golongan } \\
\text { Sedang }\end{array}$ & $\begin{array}{c}\text { Petani } \\
\text { Golongan } \\
\text { Rendah }\end{array}$ \\
\hline Petani padi & 19 & 28 & 21 \\
\hline Petani sayur & 78 & 46 & 74 \\
\hline Buruh tani & 3 & 26 & 5 \\
\hline Total & 100 & 100 & 100 \\
\hline
\end{tabular}

Tabel 3 Persentase pendapatan responden per tahun dari sektor non-pertanian pada setiap golongan pendapatan menurut sumbernya tahun 2012

\begin{tabular}{lrrr}
\hline & \multicolumn{3}{c}{$\begin{array}{c}\text { Persentase pendapatan rumahtangga/ } \\
\text { tahun (\%) }\end{array}$} \\
\cline { 2 - 4 } Sumber pendapatan & $\begin{array}{c}\text { Petani Golon- } \\
\text { gan Tinggi }\end{array}$ & $\begin{array}{c}\text { Petani } \\
\text { Golongan } \\
\text { Sedang }\end{array}$ & $\begin{array}{c}\text { Petani } \\
\text { Golongan } \\
\text { Rendah }\end{array}$ \\
\hline Pedagang ternak & 20 & 5 & 20 \\
Pedagang di pasar & 2 & 13 & 16 \\
Warung & 34 & 0 & 0 \\
$\begin{array}{l}\text { Buruh bangunan } \\
\text { Buruh hutan/ }\end{array}$ & 3 & 3 & 37 \\
karyawan & 19 & 28 & 0 \\
$\begin{array}{l}\text { Tukang ojek } \\
\text { Kiriman (hasil mi- } \\
\text { grasi) }\end{array}$ & 0 & 20 & 6 \\
Total & 22 & 32 & 21 \\
\hline
\end{tabular}

Tabel 4 Persentase kontribusi sumber pendapatan pertanian dan non-pertanian terhadap rata-rata pendapatan responden per tahun pada tahun 2012

\begin{tabular}{lr}
\hline \multicolumn{1}{c}{ Sumber pendapatan } & $\begin{array}{c}\text { Persentase pendapatan rumahtangga/ } \\
\text { tahun }(\%)\end{array}$ \\
\hline Pertanian & 57 \\
Non-pertanian & 43 \\
Total & 100 \\
\hline
\end{tabular}

Jika dilihat angka-angka tersebut maka dapat disimpulkan 
bahwa meskipun masyarakat mengaku pekerjaan utama mereka adalah petani, namun basis nafkah sebenarnya adalah kedua sektor nafkah yaitu pertanian dan nonpertanian. Artinya telah terjadi transformasi sosial dimana nilai pertanian bagi masyarakat cenderung menurun. Kecenderungan ini tentu saja dipengaruhi oleh kebutuhan rumahtangga yang besar.

Pengeluaran rumahtangga adalah semua jenis pengeluaran yang dikeluarkan untuk memenuhi kebutuhan seharihari serta menunjang permodalan untuk memperoleh pendapatan baru. Rata-rata pengeluaran konsumsi rumahtangga terdiri dari biaya-biaya hidup sehari-hari seperti makanan, pendidikan anak, listrik, dan transportasi.

Pengeluaran konsumsi (makanan) menjadi pengeluaran terbesar dari setiap golongan pendapatan. Rata-rata pengeluaran makanan tertinggi berasal dari golongan pendapatan rendah yaitu sebesar 79 persen. Kemudian disusul dari golongan pendapatan tinggi yaitu mencapai 74 persen dan golongan pendapatan sedang sebesar 68 persen. Pengeluaran pendidikan dimana golongan pendapatan rendah sebesar 10 persen, golongan pendapatan sedang sebesar 19 persen, dan golongan pendapatan tinggi sebesar 14 persen. Setelahnya disusul pengeluaran untuk listrik dan transportasi yang hanya sebesar lima sampai tujuh persen.

Tabel 5 Persentase pengeluaran responden per tahun pada setiap golongan pendapatan menurut sumber pengeluaran tahun 2012

\begin{tabular}{lrrr}
\hline & \multicolumn{3}{c}{$\begin{array}{c}\text { Persentase pengeluaran rumahtangga/tahun } \\
\text { Sumber }\end{array}$} \\
\cline { 2 - 4 } pengeluaran & $\begin{array}{c}\text { Petani Golon- } \\
\text { gan Tinggi }\end{array}$ & $\begin{array}{c}\text { Petani Golon- } \\
\text { gan Sedang }\end{array}$ & $\begin{array}{c}\text { Petani } \\
\text { Golongan } \\
\text { Rendah }\end{array}$ \\
\hline Makanan & 74 & 68 & 79 \\
Pendidikan & 14 & 19 & 10 \\
Listrik & 6 & 7 & 6 \\
Transportasi & 6 & 5 & 5 \\
Total & 100 & 100 & 100 \\
\hline
\end{tabular}

Hasil analisis tingkat kemampuan menabung (saving capacity) pun terlihat bahwa kemampuan tiap golongan pendapatan berbeda-beda. Golongan pendapatan tinggi mampu melakukan saving yang cukup besar, sedangkan golongan pendapatan rendah dan sedang tidak terlalu besar dalam hal saving. Pendapatan tinggi memiliki saving capacity mencapai 7,9 juta rupiah, sedangkan golongan sedang hanya sekitar 2,2 juta rupiah dan golongan pendapatan rendah hanya 400.000 rupiah saja. Angka ini tentu dipengaruhi dari strategi nafkah yang dijalankan oleh masyarakat.

\section{PENERAPAN RAGAM STRATEGI NAFKAH}

Penerapan strategi nafkah masyarakat di Desa Cipeuteuy sangat bervariasi. Para petani tidak hanya memanfaatkan sektor pertanian untuk memenuhi kebutuhan hidup mereka, melainkan juga sektor non-pertanian. Pada akhirnya sulit untuk dibedakan mana yang menjadi basis nafkah utama masyarakat di desa ini, apakah masih sektor pertanian atau telah beralih ke sektor non pertanian. Sistem nafkah yang dijalankan beragam, mulai dari mengintensifkan salah satu sektor, entah pertanian atau non-pertanian, diversifikasi nafkah atau pola nafkah ganda, hingga rekayasa spasial atau migrasi.

\section{Intensifikasi Pendapatan Pertanian}

Intensifikasi pendapatan pertanian artinya memanfaatkan sektor pertanian secara efektif dan efisien baik melalui penambahan input eksternal seperti teknologi dan tenaga kerja (intensifikasi), maupun dengan memperluas lahan garapan (ekstensifikasi). Untuk Intensifikasi pendapatan pertanian, cara intensifikasi melalui penambahan input eksternal belum dilakukan. Teknologi yang digunakan masih kurang berkembang akibat kondisi lahan yang berbukit-bukit dan jaraknya yang jauh. Hal ini tidak memungkinkan bagi teknologi modern untuk mencapainya. Para petani hanya menggunakan teknologi seadanya untuk menggarap lahan. Selain itu, untuk tenaga kerja pun, para petani lebih memilih menggunakan tenaga kerja keluarga daripada tenaga kerja dari luar. Mereka lebih memilih konsisten dengan hasil panen seperti biasa daripada meningkatkan hasil panen tapi harus membayar upah lebih untuk tenaga kerja.

Sedangkan cara lain yaitu ekstensifikasi sudah tentu tak bisa dilakukan mengingat lahan yang digarap oleh petani bukan merupakan lahan milik sendiri melainkan lahan dalam kawasan TNGHS. Belum lagi perjanjian dari pihak BTGNHS yang mengatakan bahwa petani boleh menggarap lahan yang sudah ada sekarang namun tak boleh memperluasnya. Maka dari itu, sistem ekstensifikasi atau berusaha memaksimalkan pendapatan dari usaha pertanian melalui perluasan lahan garapan tak bisa dilakukan.

"Sudah menjadi persetujuan antara masyarakat atau petani dengan pihak TNGHS kalau kami tidak akan memperluas lahan pertanian yang ada di dalam kawasan TNGHS. Kami juga menepati janji, takutnya kalau dilanggar malah jadi digusur seluruhnya."

(DYT, 38 tahun, tokoh masyarakat)

Pada intinya, para petanibelum mengintensifkan pendapatan pertanian. Para petani lebih memilih menambah ruang lingkup nafkahnya ke arah sektor non-pertanian. Bahkan dapat pula menjadikan sektor non-pertanian sebagai basis nafkah utamanya.

\section{Pola Nafkah Ganda}

Pola nafkah ganda (diversifikasi nafkah) dapat dilakukan dengan menerapkan keanekaragaman pola nafkah dengan cara mencari pekerjaan lain selain pertanian untuk menambah pendapatan, atau dengan mengerahkan tenaga kerja keluarga (ayah, ibu, dan anak) untuk ikut bekerja selain pertanian- dan memperoleh pendapatan.

Pola nafkah ganda dilakukan dengan mengerahkan sendisendi lain kehidupan untuk memberi jalan menambah pundi-pundi pendapatan. Pola nafkah ganda dapat dilakukan dengan berbagai cara yang pada intinya tidak hanya memanfaatkan satu sumber nafkah saja. Salah satu contoh strategi diversifikasi nafkah adalah yang terjadi pada petani kentang di Desa Karangtengah. Hasil penelitian Turasih (2011) mengemukakan strategi nafkah yang diterapkan oleh petani kentang terdiri dari strategi nafkah sektor on farm dan off farm. 
Strategi mendiversifikasi kedua sektor nafkah tadi menjadi bentuk perjuangan rumahtangga petani dalam menghadapi berbagai situasi. Aktivitas nafkah lain dilakukan di luar bertani kentang untuk bisa menghasilkan pendapatan tambahan. Meskipun begitu, usaha tani kentang masih tetap menjadi andalan untuk menopang perekonomian rumahtangga, bahkan disaat krisis. Hanya saja pada saat krisis, petani kentang harus melakukan hutang modal pertanian kepada petani kaya, kerabat dekat, dan juragan kentang. Aktivitas hutang ini didasarkan pada hubungan kepercayaan dan akan dibayar pada saat musim panen tiba.

Basis nafkah utama masyarakat di Desa Cipeuteuy juga sebagai petani, baik petani padi maupun petani sayur, sama halnya dengan petani kentang yang menjadikan kentang sebagai andalan penopang perekonomian,. Ratarata para petani di Desa Cipeuteuy pun melakukan hal sama yaitu strategi diversifikasi nafkah. Mereka tidak hanya menggantungkan kehidupannya pada sektor pertanian melainkan juga pada sektor lain di luar pertanian. Penghasilan dari sektor pertanian terhitung kecil dan tak mampu mencukupi kebutuhan hidup sehari-hari, mulai dari pangan, pendidikan, listrik, dan sebagainya.

Sektor pertanian yang dilakukan warga juga dibatasi oleh akses petani terhadap lahan. Bisa dikatakan, akses petani terhadap lahan yang dipinjam dari TNGHS belum sepenuhnya bebas. Permasalahan pemanfaatan lahan yang dibatasi oleh sistem zonasi dan larangan perluasan menyebabkan petani tak dapat mengintensifkan pendapatannya melalui sektor pertanian. Maka dari itu, sektor non-pertanian menjadi sektor pendukung yang tepat bagi petani untuk mencukupi kebutuhan rumahtangga.

Sektor non-pertanian yang dijalankan oleh masyarakat telah jelas ditampilkan pada bagian bab struktur nafkah. Pekerjaan-pekerjaan tersebut antara lain menjadi tukang ojek, pedagang ternak, pedagang di pasar, buruh hutan, buruh bangunan, karyawan, pedagang warung, dan sebagainya. Terdapat perbedaan pada tiap lapisan masyarakat yaitu pada jenis pekerjaan dari sektor nonpertanian yang menjadi penyumbang pendapatan terbesar.

Pemasukan terbesar pada golongan pendapatan tinggi berasal dari usaha berdagang di warung yaitu 34 persen. Lalu pada golongan pendapatan sedang, pemasukan terbesar berasal dari kiriman anggota keluarga yang bekerja di luar desa yaitu sebesar 32 persen. Terakhir pada golongan pendapatan rendah, pemasukan terbesar dari pekerjaan sebagai buruh bangunan yaitu mencapai 37 persen (Lihat tabel 8 dan tabel 9).

Pola nafkah ganda berarti tidak hanya berada pada basis nafkah utama namun juga memanfaatkan waktu dan kesempatan di luar basis tersebut. Pemanfaatan sektor non-pertanian dan bermigrasi menjadi salah satu cara mereka untuk menambah pendapatan. Maka dari itu, warga memilih melakukan strategi lain di luar pertanian seperti menjadi pedagang, buruh, atau menawarkan jasa. Cara lain yang dilakukan ada migrasi ke luar desa, baik dilakukan sendiri maupun oleh anggota keluarga yang lain dalam rumahtangga. Kegiatan di luar pertanian dan migrasi ini akan dijelaskan lebih lanjut pada subbab berikutnya.

\section{Intensifikasi Pendapatan Non-Pertanian}

Intensifikasi strategi non-pertanian berarti memanfaatkan sektor non-pertanian dengan lebih efektif dan efisien melalui penerapan beragam pekerjaan di luar sektor pertanian untuk meningkatkan pendapatan. Pendapatan dari sektor non-pertanian memang memberikan harapan besar bagi para petani untuk meningkatkan pendapatan rumahtangganya.

Data-data pada bab sebelumnya memperlihatkan data mengenai pendapatan yang diperoleh oleh masyarakat dari kedua sektor nafkah. Pendapatan dari sektor non-pertanian sebesar 48 persen sedangkan pendapatan dari sektor pertanian sebesar 52 persen. Meskipun pendapatan dari sektor pertanian masih lebih besar daripada pendapatan dari sektor non-pertanian namun melihat basis bafkah masyarakat adalah petani, angka ini tergolong cukup tinggi.

Strategi non-pertanian yang banyak dilakukan oleh para petani adalah mengintensifkan kegiatan seperti menjadi tukang ojek, pedagang, buruh, dan lainnya. Kegiatan menjadi tukang ojek cukup mudah dilakukan selama memiliki alat transportasi berupa motor. Ongkos satu kali menggunakan jasa ojek ke pasar sekitar 50.000 rupiah. Hal ini karena letak pasar yang berada jauh dari desa dan harus ditempuh sekitar dua jam perjalanan. Namun sekarang ini, jasa tukang ojek kurang dipergunakan karena rata-rata warga telah memiliki motor pribadi.

Kegiatan non-pertanian lain yang menyumbang pendapatan adalah menjadi pedagang. Pedagang pun beragam kategorinya, ada yang menjadi pedagang warung, pedagang di pasar, dan pedagang ternak. Berdagang dengan membuka warung dipinggir jalan hanya dilakukan oleh segelintir warga. Hal ini karena warung harus dibuka dan ditunggui sepanjang hari sehingga tidak leluasa untuk melakukan pekerjaan lain. Begitupun berdagang di pasar, hanya dilakukan pada waktu-waktu tertentu. Biasanya untuk mencari modal tambahan untuk kegiatan pertanian.

Kegiatan berdagang ternak pun tidak bisa dilakukan setiap hari melainkan hanya sekali atau dua kali setahun. Hal ini karena ternak harus ditunggu berumur minimal satu sampai satu setengah tahun untuk berkembang biak sebelum dijual. Namun penghasilan dari menjual ternak seperti kambing bisa mencapai 800.000 rupiah untuk kambing jantan dan 400.000 rupiah untuk kambing betina.

Strategi nafkah lainnya yang dilakukan adalah menjadi buruh, baik menjadi buruh bangunan maupun menjadi buruh hutan. Kegiatan menjadi buruh hutan hanya dilakukan oleh sedikit petani karena kegiatan buruh hutan adalah membantu penelitian yang dilakukan di kawasan hutan konsevasi TNGHS. Sedangkan menjadi buruh bangunan rata-rata dilakukan oleh golongan berpendapatan rendah. Namun kegiatan ini juga jarang dilakukan karena dalam satu tahun tidak banyak warga yang membangun rumah.

\section{Strategi Migrasi}

Rekayasa spasial (migrasi) merupakan usaha yang dilakukan dengan melakukan mobilitas ke daerah lain di luar desanya, baik secara permanen maupun sirkuler untuk memperoleh pendapatan. Di Desa Cipeuteuy, migrasi secara sirkuler maupun permanen juga dilakukan. Migrasi permanen dilakukan oleh anggota keluarga tidak memiliki pekerjaan tetap di desa sehingga lebih memilih merantau ke luar desa. Terbukti bahwa pada dari sebelas responden 
yang anggota keluarganya bermigrasi, hampir 25 persen pendapatan non-pertaniannya disumbangkan oleh kiriman dari keluarga yang bekerja di luar desa.

Migrasi sirkuler kadang terjadi ketika musim paceklik tiba. Petani yang tidak memiliki modal untuk memulai kegiatan pertanian baru memilih untuk melakukan migrasi sirkuler dengan menjadi pedagang di pasar. Mereka sedikit demi sedikit mengumpulkan modal untuk mulai bercocok tanam di lahan pertanian mereka.

Intinya, migrasi menjadi salah satu cara yang dilakukan oleh para petani untuk membantu menunjang strategi nafkah mereka. Meskipun pada dasarnya migrasi tersebut hanya dilakukan pada waktu-waktu tertentu seperti ketika musim paceklik berakhir. Pendapatan dari sektor pertanian yang tidak mencukupi untuk modal baru menjadi alasan mereka melakukan migrasi.

\section{SIMPULAN DAN SARAN}

\section{Simpulan}

Pola kepemilikan lahan di Desa Cipeuteuy antara lain kepemilikan melalui warisan dan jual beli. Kepemilikan lahan melalui sistem waris lebih banyak dibandingkan melalui jual beli karena rata-rata masyarakat tidak menjual lahan, melainkan menggunakannya untuk kegiatan pertanian. Sedangkan pola penguasaan lahan di desa ini antara lain sistem pinjam-pakai yang digunakan pada lahan di dalam kawasan TNGHS, sistem bagi hasil yang digunakan untuk lahan milik orang luar desa, dan juga lahan eks HGU PT. Intan Hepta. Khusus untuk lahan di kawasan TNGHS, terdapat sistem zonasi yang mengatur kawasan-kawasan yang boleh dimanfaatkan dan yang dilarang dimanfaatkan untuk kegiatan di luar konservasi. Hal ini berakibat pada status penguasaan lahan yang tidak aman bagi para petani pemanfaat lahan dan berpengaruh pada strategi nafkah yang mereka jalankan.

Sumbangan sektor pertanian dan sektor non-pertanian terhadap pendapatan rata-rata rumahtangga responden per tahun dari semua golongan pendapatan hampir seimbang. Pendapatan yang diperoleh oleh responden dari sektor non-pertanian adalah sebesar 43 persen dan dari sektor pertanian sebesar 57 persen. Pada golongan pendapatan sedang, kontribusi farm sebesar 62 persen sedangkan nonfarm sebesar 38 persen. Terakhir pada golongan pendapatan rendah, kontribusi farm sebesar 73 persen dan non-farm sebesar 27 persen. Maka dari itu, disimpulkan bahwa basis nafkah para petani di Desa Cipeuteuy adalah pertanian dan non-pertanian. Penerapan strategi nafkah pun menjadi beragam dengan memanfaatkan sektor pertanian dan nonpertanian. Strategi nafkah tersebut diantaranya:

\section{Golongan pendapatan tinggi cenderung melakukan:}

a. Strategi intensifikasi pendapatan non-pertanian, terlihat dari banyaknya jenis pekerjaan yang dilakoni seperti menjadi buruh bangunan, buruh hutan, pedagang warung, pedagang ternak, hingga menjadi tukang ojek.

b. Strategi pola nafkah ganda juga banyak dipilih karena memaksimalkan pendapatan dari kedua sektor nafkah.

2. Golongan pendapatan sedang cenderung melakukan: a. Strategi pola nafkah ganda juga banyak dipilih karena memaksimalkan pendapatan dari kedua sektor nafkah.

b. Strategi migrasi. Biasanya petani memanfaatkan keberadaan anak atau anggota keluarga yang bekerja di luar desa untuk mendapat penghasilan tambahan.

\section{Golongan pendapatan rendah cenderung melakukan:}

a. Strategi intensifikasi pendapatan pertanian biasanya dilakukan dengan menambah input produksi. Namun dalam kasus rumahtangga petani golongan rendah di desa ini, intensifikasi pendapatan pertanian belum dilakukan secara maksimal. Hal ini dipengaruhi oleh lahan pertanian yang bukan milik sendiri dan tidak dapat diperluas.

b. Strategi pola nafkah ganda juga banyak dipilih karena memaksimalkan pendapatan dari kedua sektor nafkah.

Strategi pola nafkah ganda juga banyak dipilih karena memaksimalkan pendapatan dari kedua sektor nafkah. Strategi nafkah tersebut dipengaruhi oleh penggunaan lahan pertanian yang masih bergantung pada lahan TNGHS. Petani pemanfaat lahan TNGHS harus bertani dengan dibarengi rasa cemas akan pengambilalihan kembali lahan pertanian mereka. tentu hal ini tidak akan terjadi jika mereka menggunakan lahan milik sendiri. Itu sebabnya strategi intensifikasi pendapatan pertanian tidak dilakukan. Petani lebih cenderung mengintensifkan sektor non-pertanian atau diversifikasi nafkah untuk mencukupi kebutuhan ekonomi rumahtangganya.

\section{Saran}

Saran yang dapat diberikan oleh peneliti adalah proses peneguhan dalam persoalan penguasaan lahan masyarakat di Desa Cipeuteuy. Pasalnya, perjanjian pinjam pakai lahan di TNGHS masih berupa perjanjian lisan tanpa ada bukti surat keterangan. Perjanjian tertulis disarankan agar kedua belah pihak bisa dengan tenang menjalankan aktivitasnya masing-masing. Terutama bagi para petani pemanfaat lahan dimana perjanjian dan aturan tertulis bisa memberikan rasa aman bagi mereka untuk bercocok tanam dengan tenang meskipun bukan di lahan milik mereka sendiri. Jika petani dapat memiliki rasa aman tersebut, tentu saja petani dapat lebih memaksimalkan sektor pertanian yang menjadi basis nafkah mereka sejak dulu.

\section{DAFTAR PUSTAKA}

Dharmawan AH. 2007. Sistem penghidupan dan nafkah pedesaan: pandangan sosiologi nafkah (livelihood sociology) mahzab barat dan mahzab Bogor. Sodality. Volume 01 Nomor 02. [Internet]. Dapat diunduh dari: http://jurnalsodality.ipb.ac.id/index. $\mathrm{php} / \mathrm{component} / \mathrm{sodality} / \mathrm{id}=86 \&$ task $=$ view tanggal 23 Maret 2012 pukul 20.00 WIB. Hal 169192.

Ellis F. 2000. Rural livelihoods and diversity in developing countries. New York: Oxford University Press.

Fauzi N. 1999. Petani dan penguasa: dinamika perjalanan politik agraria Indonesia. Yogyakarta [ID]: INSIST, KPA, dan Pustaka Pelajar Offset. 316 hal.

Fuad FH, Maskanah S. 2000. Inovasi penyelesaian 
sengketa pengelolaan sumber daya hutan. Pustaka LATIN: Bogor

Helmi F. 2010. Kontestasi penguasaan sumber daya hutan di Provinsi Aceh: kasus Desa Jamur Konyel, Kec. Bintang, Kab. Aceh Tengah, Provinsi Aceh. [Skripsi]. Bogor [ID]: Institut Pertanian Bogor.

Kuswijayanti ER. 2007. Konservasi sumberdaya alam di Taman Nasional Gunung Merapi: analisis ekologi politik. [Tesis]. Bogor [ID]: Institut Pertanian Bogor.

Marina I. 2011. Analisis konflik sumberdaya hutan di kawasan konservasi (studi kasus Kampung Sinar Resmi, Desa Sinar Resmi, Kecamatan Cisolok, Kabupaten Sukabumi, Provinsi Jawa Barat). [Skripsi]. Bogor [ID]: Institut Pertanian Bogor.

Niswah ZK. 2011. Strategi nafkah masyarakat adat kasepuhan sinar resmi di Taman Nasional Gunung Halimun Salak. [Skripsi]. Bogor [ID]: Institut Pertanian Bogor.

Nurhaeni A. 2009. Implikasi penunjukan areal konservasi terhadap pengelolaan hutan dan luas lahan (studi kasus Taman Nasional Gunung Halimun-Salak Desa Cirompang, Kec. Sobang, Kab. Lebak, Jawa Barat). [Skripsi]. Bogor [ID]: Institut Pertanian Bogor.

Pamulardi B. 1995. Hukum kehutanan dan pembangunan bidang kehutanan. Jakarta [ID]: Manajemen PT Raja Grafindo Persada. 426 hal.

Priyanto F. 2011. Dampak zonasi taman nasional karimunjawa terhadap strategi nafkah nelayan kompressor (kasus Desa Karimunjawa, Kecamatan Karimunjawa, Kabupaten Jepara, Provinsi Jawa Tengah). [Skripsi]. Bogor [ID]: Institut Pertanian Bogor.

Purnomo AM, Dharmawan AH, Agusta I. 2007. Transformasi struktur nafkah pedesaan: pertumbuhan "modal sosial bentukan" dalam skema pengelolaan hutan bersama masyarakat di Kabupaten Kuningan. Sodality. Volume 01 Nomor 02. [Internet]. Dapat diunduh di: http:// jurnalsodality.ipb.ac.id/index.php/component/ sodality/?id=27\&task=view tanggal 18 Maret 2012 pukul 13.30 WIB. Hal 193-206.

Rinaldi D, Harahap SA, Prawiradilaga DM, Wiriadinata H, Purwaningsih, Sambas E, Febriana I, Ningrum IK, Faizin N. 2008. Ekologi koridor Halimun-Salak: Taman Nasional Gunung Halimun Salak. Sukabumi [ID]: Taman Nasional Gunung Halimun Salak dan Gunung Halimun-Salak National Park Management Project. 50 hal.

Santoso U. 2005. Hukum agraria dan hak-hak atas tanah. Jakarta [ID]: Kencana Prenada Media Group.

Sardi I. 2010. Konflik sosial dalam pemanfaatan sumberdaya hutan (studi kasus di Taman Nasional Bukit Duabelas Propinsi Jambi). [Tesis]. Bogor [ID]: Institut Pertanian Bogor.

Sihaloho M. 2004. Konversi lahan pertanian dan perubahan struktur agraria (studi kasus di Kelurahan Mulyaharja, Kecamatan Bogor Selatan, Kota Bogor, Jawa Barat). [Tesis]. Bogor [ID]: Institut Pertanian Bogor.

Singarimbun M, Effendi S. 1989. Metode penelitian survai. LP3ES: Jakarta. 346 hal.

Sunarsih. 2004. Strategi nafkah rumahtangga petani lahan kering (kasus komunitas petani lahan kering di Desa Losilang, Kecamatan Kajang, Kabupaten Bulukumba, Sulawesi Selatan). [Skripsi]. Bogor [ID]: Institut Pertanian Bogor. 178 hal.

Sutaryono. 2008. Pemberdayaan setengah hati: sub ordinasi masyarakat lokal dalam pengelolaan hutan. Yogyakarta [ID]: Lapera Pustaka Utama dan STPN. 180 hal.

TNGHS. 2007. Rencana pengelolaan Taman Nasional Gunung Halimun Salak periode 2007-2026. Sukabumi: TNGHS.

Turasih. 2011. Sistem nafkah rumahtangga petani kentang di Dataran Tinggi Dieng (kasus Desa Karangtengah, Kecamatan Batur, Kabupaten Banjarnegara, Provinsi Jawa Tengah). [Skripsi]. Bogor [ID]: Institut Pertanian Bogor. 113 hal.

Widiyanto, Dharmawan AH, Prasodjo NW. 2010. Strategi nafkah rumahtangga petani tembakau di Lereng Gunung Sumbing (studi kasus di Desa Wonotirto dan Desa Campursari, Kecamatan Bulu, Kabupaten Temanggung). Sodality. Volume 04 Nomor 01. [Internet]. Dapat diunduh dari: http:// jurnalsodality.ipb.ac.id/index.php/component/ sodality/?id=86\&task=view tanggal 23 Maret 2012 pukul 20.00 WIB. Hal 91-114.

Wiradi G. 2000. Reforma agraria: perjalanan yang belum berakhir. Bandung [ID]: KPA, Sajogyo Institute, dan AKATIGA. 200 hal.

Wiradi G. 2009a. Seluk beluk masalah agraria: reforma agraria dan penelitian agraria. Yogyakarta [ID]: STPN Press. 294 hal.

Wiradi G. 2009b. Metodologi studi agraria: karya terpilih Gunawan Wiradi. Bogor: Sajogyo Institut, Departemen Sains Komunikasi dan Pengembangan Masyarakat Fakultas Ekologi Manusia IPB, dan Pusat Kajian Agraria IPB. 388 hal.

Wiradi G, Makali. 2009. Ranah studi agraria: penguasaan tanah dan hubungan agraris. Shohibuddin M, editor. Yogyakarta: STPN Press dan Sajogyo Institut. 422 hal. 